\title{
Development of Marketing Mix Strategy for Spa Business
}

\author{
Nalin Simasathiansophon
}

\begin{abstract}
This research aims to study the marketing mix of sea salt spa enterprise in order to develop guideline to improve marketing mix for sea salt spa small enterprise. The samples had been selected using homogeneous sampling method. The questions related with $5 P$ s marketing mix in spa industry; product, price, place, promotion, and personnel.

The result of this research showed that all 5Ps marketing mix affected the operation of sea salt spa. Product was the most important factor that affects customers' preferences since it directly contacts with customers. The second important factor was personnel. An owner should provide a social welfare as well as develop a good relationship among owner and worker. As a result, workers will, in turn, offer a high-class service to customers. Price setting must be carefully calculated with consideration of fixed and variable costs plus a required profit. However, it should not be higher than common price of similar product sells by competitors. Finally, promotion campaigns could be set regarding to point of sale. For instance, customer can get a free hand treatment before buying a product.
\end{abstract}

Keywords: Health tourism, Spa, Sea salt, Marketing mix.

\section{INTRODUCTION}

Recently, tourism industry is playing an important role in developing economies, including Thailand. Increasing number of travelers each year indicates the inflow money to the country. Some destinations in Thailand, however, has less ability to serve high number of travelers at the same time. In this case, the collaboration between private and government sectors are needed to increase ability to cope with numbers of travelers as well as to increase the readiness of destination for supporting foreign travelers. This has been considered to be main important strategy for Thailand in order to increase market share in this highly competitive market.

Due to the changing perspective of travelers to health tourism trend, there is emergence of new group of tourists. They tend to focus on getting experiences through participating with local activities that concern with healthcare. This trend creates new health promotion services, such as spa, massage, and beauty business. This new business is the main focus of the government strategic planning in year 2017 [1]. Nevertheless, the density of tourism still places among the big cities, such as Bangkok, Phuket, Pattaya, and Chiang Mai [2]. So, there is a need to develop destination in another cities, especially the cities along the west coast of Thailand, so called Royal Coast. These cities, Phetchaburi, Prachuap Khiri Khan, and Chumphon are destinations for those who love cultural, environmental and coastal, and

Revised Version Manuscript Received on 16 September, 2019.

* Correspondence Author

Nalin Simasathiansophon, Lecturer, International College, Suan Sunandha Rajabhat University, Bangkok, Thailand, E-mail: nalin.si@ssru.ac.th health tourism. However, they still need to enhance infrastructure to link logistic systematically, add value for tourism service, improve quality and standard of tourism, manage sustainably environment, and increase capability of human resources in order to conduct a strategic plan for improving capability of destination for supporting numbers of travelers in the near future [3].

Phetchaburi, a city with various cultures and local wisdom, is famous in farming a sea salt for many years. The process of sea salt production has been transferred over generations using environmental process, especially sun light. The production can take around 4 to 5 months or more if there is a heavy rain. Thus, the final product may be less in number comparing with the time spent for production. Because of this uncertain process, the sea salt process is hard to inherit to the new generation. Therefore, to protect this knowledge, the salt farmers in Phetchaburi has added value by offering salt faming experience together with selling salt products. Business relates with this value-added tourism is spa business. These firms, often be small and medium enterprises (SMEs), are normally selling salt products that has special qualification of relaxing physique and mentality together with offering spa or massage [4]. Thus, supporting this spa business can help increase income for those salt farmers.

Because of this problem, the researcher wants to increase competency of those salt spa business to attract more travelers and customers to Phetchaburi. To do this, marketing mix has been exploited to identify appropriate strategy for small enterprises offering sea salt spa so that they can apply this marketing mix with their business in the future.

\section{LiterATURE REVIEW}

\subsection{Spa Business and Health Promotion Service}

Ministry of Public Health has given the definition of healthcare spa as a business that provides health treatment and support through massage and the use of water. The promotion service includes exercise, nutritional and diet therapy, yoga and meditation, herb therapy, and other alternative medicines. Spa is a Latin language of 'Sanus per aquam' meaning health from water and water therapy. Traditionally, types of spa categorize regarding to its activities. Health spa service refers to a business that offers care and health support through massage and water therapy. Massage spa includes Thai massage, body massage, and facial treatment. The last type is medical spa service means spa for beauty treatment, such as computer-aided cosmetology instrument (CACI) face-lifts, Botox injections, laser hair removal, and microdermabrasion [5]. The International Spa Association (ISPA) also divides spa business according to its location. Club spa provides fitness and variety of professionally administered spa

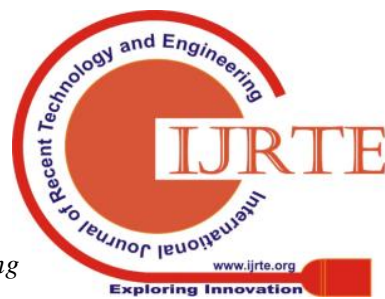


services on a day-use basis. Day spa offers a variety of professional administered spa services to clients on a day-use basis. Destination spa is a facility with the primary purpose of guiding individual spa-goers to develop healthy habits. This type of spa provides a comprehensive program that includes spa services, physical fitness activities, wellness education, healthful cuisine and special interest programming. Medical spa offers a facility that has a full-time licensed health care professional on-site, which is further defined as a health professional who has earned a degree of Doctor of Medicine (M.D.). All applications are reviewed individually, and international standards are taken into account. Mineral spring spa provides an on-site source of natural mineral, thermal or seawater used in hydrotherapy treatments. Resort or hotel spa located within a resort or hotel provides professionally administered spa services, fitness and wellness components. Lastly, cruise ship spa located on cruise or large ship offers spa services, fitness and other wellness components [6].

Spa business and health promotion service in Thailand has continue increasing in number since 2012. Currently, number of registered business-pass the spa standard set by Ministry of Public Health-is around 2,053 enterprises. Table 1 indicates number of registered spa business regarding to types of spa [7].

Table 1. Number of Spa Business Regarding to Types of Spa (made by the author)

\begin{tabular}{|l|c|c|}
\hline \multicolumn{1}{|c|}{ Types of spa } & $\begin{array}{c}\text { Number of } \\
\text { business }\end{array}$ & Average \\
\hline Health spa service & 531 & 25.86 \\
\hline Massage spa service & 1,217 & 59.28 \\
\hline Medical spa service & 305 & 14.86 \\
\hline Total & $\mathbf{2 , 0 5 3}$ & $\mathbf{1 0 0 . 0 0}$ \\
\hline
\end{tabular}

Due to the increasing of spa business, money inflow into spa industry grows as well. Department of International Trade and Promotion, Ministry of Commerce has announced that the revenue from spa industry in year 2013 is around 979.7 million US dollar with 22.5 million of customers. In year 2014 spa industry grows around 7 percent and in year 2015 grows around 16 percent as shown in figure 1 .

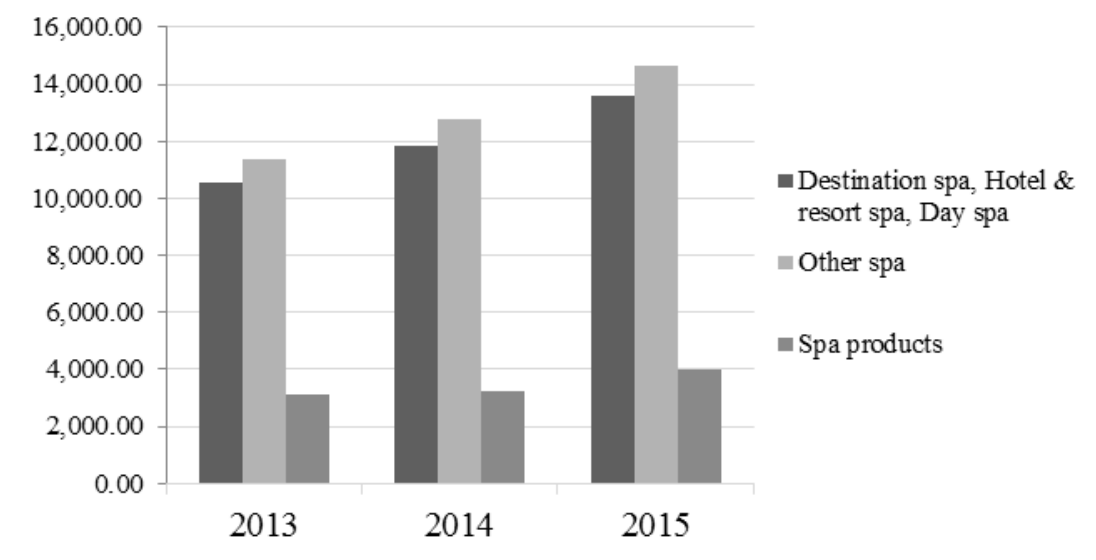

Figure 1. Value of Thai Spa Industry in Year 2013 - 2015

Tezak et al. who study the 3 level of influences of wellness in selecting tourism destination in 5 resorts in Istria, Kroatia using Chi-square and One-Way ANOVA analyzing method suggested that different level of health care concern among the customers can affect their choice of destinations [8]. This result is also supported by the research of Chanin et. al. in year 2015 that consumers behavior and preferences are highly related with the way they select the destination and purpose of traveling [9]. Thus, destination selection often has a high effect on travelers' decision-making.

\subsection{Service Marketing Mix}

Kotler \& Armstrong has suggested that there are 7 marketing mix for service industry includes; product/service, price, distribution or place, promotion, personal, physical and process [10]. For this research, however, the marketing mix developed by Office of Small and Medium Enterprises Promotion which made especially for spa industry will be applied. There are five elements; product/service, price, place, promotion, and personnel. Product/service is spa service with five senses including vision, hearing, smell, taste, and touch. Price tells customers about value of products or service. Place identifies the location of point of service. Promotion increases recognition of brand among target market. Finally, personnel deals with skilled workforces that can create value to customers.

From the research of Chantaburee on the opportunity and competitiveness of spa business in Thailand using in-depth interview and small group work for brain storming, the result shows that Thai spa has grown continuously, generating more revenue to tourism industry. However, finding source of fund and skilled workers still be a barrier to success for this industry [11]. This result is consistent with the research of Wutthiwatthanakul who studies the effect of marketing mix, attitude, and living style on consumer selection of spa service in Nontaburi province, Thailand. By analyzing hypothesis using multiple linear regression, the result illustrates that marketing mix, attitude, and living style affects the way customers selecting spa service [12]. Moreover, the work of Hoang et. al. [13] and Seyidov and Adomaitiene [14] also supported the fact that

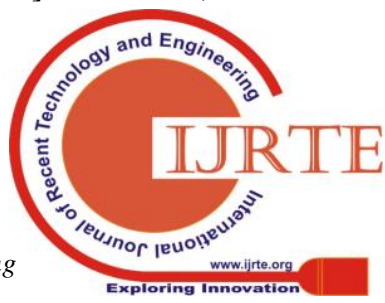




\begin{tabular}{|c|c|}
\hline & $\begin{array}{l}\text { - All equipments should have a user manual } \\
\text { 3. Aromatherapy } \\
\text { - Essential oil should made by herbs or natural ingredients } \\
\text { - Provide a good sense of smell while service customers } \\
\text { 4. Sound } \\
\text { - Use light music for customers' relaxation } \\
\text { 5. Service } \\
\text { - Provide basic spa services, such as body massage, body and foot scrub, face mask } \\
\text { - Have well trained service providers } \\
\text { - Provide herbal drink } \\
\text { - Have a service manual }\end{array}$ \\
\hline Price & $\begin{array}{l}\text { 1. Spa service pricing method } \\
\text { - Setting a spa price should consider the cost of workforce and the product used in spa } \\
\text { operation and the price should be apparently listed on the menu } \\
\text { 2. Product pricing method } \\
\text { - Mark-up pricing: adding profit margin to the product costs } \\
\text { - Going-rate pricing: comparing price with competitors }\end{array}$ \\
\hline $\begin{array}{l}\text { Place/Distribution } \\
\text { Channel }\end{array}$ & $\begin{array}{l}\text { 1. Various distribution channels, such as shop, website, e-commerce, etc. } \\
\text { 2. Provide rest area in the spa shop }\end{array}$ \\
\hline Promotion & $\begin{array}{l}\text { 1. Offer product and service testing } \\
\text { 2. Build a brand recognition through exhibition, road show, and online advertisement } \\
\text { 3. Build a brand awareness by getting a support from government or private } \\
\text { organization }\end{array}$ \\
\hline Personnel & $\begin{array}{l}\text { 1. Owner of the spa shop } \\
\text { - Well manage customer relationship } \\
\text { - Have excellent communication skill } \\
\text { - Have ability to do a marketing plan } \\
\text { - Have a good relationship with employees } \\
\text { - Provide consistent training to employees } \\
\text { - Have a well-organized business plan } \\
\text { 2. Service providers or employees } \\
\text { - Have a good communication skill } \\
\text { - Well trained } \\
\text { - Have high service experience and create first impression to customers } \\
\text { - Have a good relationship with customers and colleagues } \\
\text { - Maintain cleanliness and tidiness of products and spa equipment } \\
\text { - Be able to provide information about products and spa service }\end{array}$ \\
\hline
\end{tabular}

Table 2 indicates that all five elements are playing as important criteria for successful spa business. Among these five, product/service is the most important element since customers get direct experience of all five senses through the spa service. Thus, atmosphere of the spa, environment, spa equipment, and products are the main factors that can affect customers' decision making. Providing a spa service requires well trained service providers, thus personnel element is considered the second important strategy. Price setting can also affect the way customers make a decision. Often, customers are sensitive with price changing. So, setting the price by comparing with competitors' price can minimize customers' switching cost. The small spa shop should promote their products and service through the selective distribution channel in order to reduce cost of promotion.

\section{CONCLUSION AND RECOMMENDATION}

In conclusion, marketing mix for a small spa business consists of five elements; product/service, price, place or distribution channel, promotion, and personnel. For product/service element, all five senses should be meet when providing spa service to customers. This element focuses, particularly, taste sense which can influence customers' decision making. All spa equipment should have a user manual to ensure that all employees will follow the use instruction. Moreover, all products should have label that states benefit and information of that products so that customers can easily decide to purchase. In terms of service, the spa shop can also provide other services, such as face mask, body and foot scrub to attract new customers.

The second element, price, can help attracting customers if the price of products and service are similar with those of competitors. Place or distribution channel also plays an important role in building a brand recognition to new group of customers or travelers. Various channels will increase the purchasing point for customers or travelers within and outside Thailand.

The small spa shop should also promote their products and service through various method, such as participating in exhibition or road show. They should also use product testing since customers tend to purchase a spa service based on their direct experience. Finally, personnel element also put a high effect to customers' or travelers' decision. Owner needs to support and encourage employees to train their skill continually.

Building relationship with both customers and employees is the key to success.

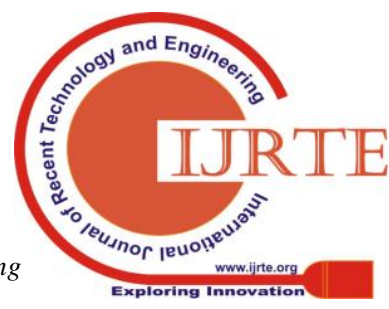


Furthermore, maintain standard with attentive service could increase customers' impression and, in turn, create customers' satisfaction. This result is consistent with the research of Thammasane [17] who found that most spa entrepreneurs has well spa knowledge and experience in terms of spa skills. Customers normally attracted by hospitality of service provider [18, 19]. Although spa entrepreneurs were highly capable in management and training their employees, they still lacked of marketing communication skills and network building.

Although this guideline can help small spa business managing their success, the research has conducted with only one well-know spa business. Thus, for further generalized result, increasing number of sample is needed. The research should also further compare this marketing mix of spa business with other similar industry to see whether any differences between industry can cause changes to customers' decision.

\section{ACKNOWLEDGEMENT}

This research would not be possible without the support of many people. The author would like to thank Assistant Professor Dr.Krongthong Khairiree who were offered a valuable assistance, support and guidance with this paper. Special thanks also to Associate Professor Tassani Siriwan for giving insightful suggestions on interview questions. I would also like to show the greatest appreciation to Mr.Sompong Noosarn, owner of Kanghuntong Sea Salt Spa for giving information about marketing strategy and spa operation. Furthermore, I would like to express gratitude to Suan Sunandha Rajabhat University to give me a supportive of both fund and suggestion in every step. Last but not least, I want to thank my parents for their endless love and support for this paper.

\section{REFERENCES}

[1] Department of Trade Negotiations (2011). Service Business: Spa and Thai Massage. Department of Trade Negotiations, Bangkok.

[2] Office of Permanent Secretary, Ministry of Tourism and Sports (2015). ASEAN Connect and Tourism in Thailand, Report of Tourism Economie, 2: 43 .

[3] Department of Rural Roads (2013), Royal Coast Road, http://www.drr.go.th/sites/default/files/attachment/vi_travel/8_petburi .pdf

[4] Office of Small and Medium Enterprises Promotion (2014), Report on Small and Medium Enterprises Situation in 2014, Office of Small and Medium Enterprises Promotion, Bangkok.

[5] Department of Health Service Support (2008), Quality Standard of Spa Business,

http://www.rno.moph.go.th/SSJblog/fda_ranong/spa/kanrubrong.pdf.

[6] International Spa Association (2017), Spa-Goers, https://experienceispa.com/resources/spa-goers.

[7] Department of International Trade Promotion, Ministry of Commerce (2015), "Thai Spa Business", http://www.ditp.go.th/contents_attach/143532/143532.pdf.

[8] Tezak, A., Saftic, D., \& Persuric, A. S. (2011), Influence of Wellness in Selecting Tourism Destination, The 5th International Scientific Conference Entrepreneurship and Macroeconomic Management: Reflections on the World in Turmoil. 3: 1918-1933.

[9] Chanin, O., Khunchumnan, P., Amphansookko, S., Thongyai, K., Rodneum, J., \& Sriprasert, P. (2015), Guideline on Health Tourism Management for Middle Eastern Tourists in Phuket Province, Procedia Computer Science, 65: 1146-1153.

[10] Kotler, P., \& Armstrong, G. (2010), Principles of Marketing, Pearson Prentice Hall, 13 Edition, United States
[11] Chantaburee, S. (2016), Opportunity and Competitiveness of Spa and Thai Massage Business in Thailand, Kasem Bundit Journal, 17,2: 49-63.

[12] Wutthiwatthanakul, P. (2016), The Important Factors Affecting to the Selection of Healthy Spa of Consumers in Nonthaburi, Bangkok University, Bangkok.

[13] Hoang, T.P., Quang, H.T., Phuong, N.N., \& Ha, N.T. (2016), Factors Affecting the Decision of The Selection of Foreign Tourists for A Tourist Destination: A Study in Da Nang City, Vietnam, European Journal of Business and Social Sciences, 4,10: 86-97.

[14] Seyidov, J., \& Adomaitiene, R. (2016), Factors Influencing Local Tourists' Decision-Making on Choosing A Destination: A Case of Azerbaijan, Ekonomika, 95, 3: 112-127.

[15] Kanghuntong (2018), Products, http://www.kanghuntong.com

[16] Simasathiansophon, N. (2018), The Study of Marketing Mix for Small Enterprise of Sea Salt Spa, Suan Sunandha Rajabhat University, Bangkok.

[17] Thammasane, S. (2012), Capacity of Small and Medium Enterprises (SMEs) in Spa Service Business within Chonburi Province and the Potentiality Required by the Customers, Suan Sunandha Rajabhat University, Bangkok.

[18] Simasathiansophon, N., Ushakov, D. (2016). Transnationalization as a trend of the present stage of international tourism development, Actual Problem of Economics, 2.

[19] Andreeva, E., Ushakov, D. (2016). Internal regional and demographic tourists' inflows distribution as factor of national tourism competitiveness, Actual Problem of Economics, 9. 